\title{
The Impact of Human Capital and Foreign Direct Investment on Economic Growth: An Empirical Study on Jordan
}

\author{
Mustafa Mohammad Alalawneh \\ School of Economic and Management, Khazar University \\ Baku, 122 Bashir Safar-Oghlu St, Baku 1009, Azerbaijan \\ E-mail: falconengineer81@yahoo.com
}

Received: March 26, 2020 Accepted: April 24, 2020 Published: May 6, 2020

doi:10.5296/ber.v10i2.16747～URL: https://doi.org/10.5296/ber.v10i2.16747

\begin{abstract}
Human capital is a real factor in improving the investment climate and attracting foreign investment. FDI also increases human capital in the host country through the transfer of advanced technology and the rehabilitation of local labor. The importance of the study comes from Jordan's serious endeavor to attract foreign direct investment and to present itself as a rich country in human and qualified capacities. This study examines the effect of human capital and foreign direct investment on economic growth in Jordan employing Auto Regressive Distributed Lags Bounds Testing (ARDL BT) co-integration method for the spanning period from 1984 to 2018. The results indicate that there is a long- run relationship among variables. The results showed that there is a negative and statistically significant effect of human capital index (HCI) on economic growth (GWP) in the long run, and a positive and statistically significant effect of FDI (GFDI) on economic growth (GWP) in the long run. The estimation results indicate that a $1 \%$ increase in (HCI) decreases (GWP) by $0.272 \%$, and a $1 \%$ increase in (GFDI) increases (GWP) by $0.006 \%$. This study is one of the few studies that highlight the challenges facing both HC and FDI in increasing economic growth in Jordan and provides some recommendations.
\end{abstract}

Keywords: Human Capital, Foreign Direct Investment, ARDLBT, Jordan

\section{Introduction}

The early beginnings of economic theories focused on the importance of physical capital in economic activity. Attention was paid to material wealth at the expense of human, and to maximize income at the expense of expanding opportunities for people. But with the 
development of economic theory, it became clear that the national product is only an objective of economic policy, and that there are other goals such as reducing unemployment, improving education and achieving a better health (Kanchan, 2001).

Hence, human is seen as an important economic resource, the driving force of economic growth, and is similar to physical capital that must be improved and invested through health, education and training to achieve the desired economic growth (Griffin and McKinley, 1992).

Many developing countries invest in education, training and employment rehabilitation as a catalyst for FDI flows. Besides, the effect of FDI on human capital is indirectly reflected as it arises from learning and experience gained by local labors friction with multinational corporations or as a result of legislation enacted by host country governments as restrictions on these companies to ensure maximum benefit from local human capital rehabilitation (Dutt, 2006).

The Jordanian economy has a specific peculiarity that imposes itself on the decision-makers. The national economy relies heavily on remittances, aid and loans. The Jordanian economy is affected positively and negatively by external factors that are not under control, including export markets, demand for tourism, changing oil prices and global demand conditions. Added to this are the internal factors represented in the lack of natural resources, such as energy sources, the limited arable land, the scarcity of water sources, the small size of the local market, the large size of government and the public sector, the import of external labor, the brain drain and national labor. On the other hand, Jordan has qualified human resources, good infrastructure, political and social stability, and openness to the world, which provides some flexibility to face internal and external conditions and changes (Alalawneh and Ibrahimov, 2018).

Jordan also has got benefits from the advantage of the qualified human element in attracting foreign direct investment and enacted many legislations, laws, incentives and tax exemptions to attract this type of investment because of its role in transferring technology from abroad, increasing exports, reducing unemployment and increasing the expertise and efficiency of Jordanian labor. However, some studies have shown that both human investment and FDI may have negative impact on economic growth and productivity of national labor, as it is possible that the education system is quantitative and not qualitative and does not correspond to the needs of the local market and does not focus on vocational education and technical training, are therefore reflected negatively on the productivity of the worker (Goncz et.al, 2007). It is also possible that foreign direct investment can increase imports and thus cause imbalance in the trade balance and also be not accompanied by the required technology, and it is possible that the large number of tax exemptions and incentives and their mismanagement may lead to a decrease in the tax burden due to a decrease in tax revenues (Carkovic and Levine, 2002).

This paper aims to study the impact of human capital and foreign direct investment on economic growth in Jordan during the period from 1984 to 2018, and this study derives its importance because it may be the first of its kind in studying the impact of these two investments together on the Jordanian economy. In addition to Jordan's serious efforts to 
invest in the human factor to compensate for the shortage in natural resources and great interest in improving the investment climate and making Jordan a destination for foreign investments in the region, due to the role of these investments in reducing dependence on external debt, reducing unemployment, transferring technology from abroad, and achieving economic development.

\section{Literature Review}

The literary economic library is not rich in studies that show and explain the impact of human capital and foreign direct investment together on economic growth and economic development, but we find many studies that have shown the impact of each separately on the economies and productivity of countries. Some of these studies have shown a positive effect, while others have shown a negative effect. Among the studies that have shown the positive impact of human capital:

Pelinescu's study (2015), which showed that it is not possible to achieve a comprehensive and sustainable development in the European Union without the participation and contribution of the people's knowledge value and human capital, and that any development goals cannot be achieved without a good educational and training system. The study used the panel methodology, and the results showed a positive impact of human capital on the sustainable development of the European Union countries. And according to Kartal, Zhumasheva and Acaroglu study (2017) was concerned with estimating the impact of human capital on economic growth in Turkey and used education and health spending as variables representing human capital. The study used the Cobb-Douglas production function in terms of employment and physical capital as factors of production, and human capital was added to the Cobb- Douglas function. In this paper, time series data related to education, health, physical capital, employment, and growth in GDP were estimated for the period from 1960 to 2011. The results indicated the positive impact of human capital on economic growth and indicated that health policies are more effective than educational policy in order to achieve sustainable development. The study recommended implementing effective economic policies that include increasing spending on education. There is also the study of Diebolt \& Hippe (2019) which focused on investigate the long-term impact of human capital represented by education and cognitive and technical skills on sustainable development. The study showed that the accumulated human capital from the eighteenth and nineteenth centuries has a significant impact on the disparity between countries in Innovation and sustainable economic development. The study used large time data series for many countries and reached the conclusion that the basis for difference and differentiation between countries in the field of innovation and development depends on the human capital accumulated during the previous decades.

While the study of Al-Dakhili and Bin Dhiab (2018) aimed to examine the impact of economic freedom on improving the investment climate and attracting foreign direct investment, and then the effect of these foreign direct investments on achieving economic growth for the countries of the Gulf Cooperation Council during the period extending from 1995 to 2017. Based on the panel unit root test, and after proving that there is a common 
co-integrating relationship between the study variables, the study used Fully Modified Ordinary Least Square (FMOLS) and Dynamic Ordinary Least square (DOLS), and the results showed the positive effect of economic freedom in attracting FDI, as demonstrated by the findings the positive impact of foreign direct investment in increasing the economic growth rate for the countries of the Arab Gulf. With regard to the Mukhtarov and Al-Alawneh study (2019), which attempted to reveal the nature of foreign direct investment in Jordan and whether it is directed and enhanced for export or for the local market, and based on the results of stationary of the unit root and common integration, where the examination of common integration showed an integrative relationship between the variables of the study (Exports, FDI, Real Exchange Rate, and Gross Capital Formation), and by using the Autoregressive Distributed lags Bound Test (ARDLBT) on a series of time data from 1980 to 2018, the results showed a positive impact for each of FDI and Gross Capital Formation on the Exports, the negative impact of the Real Exchange Rate. Among the recent studies that also showed the positive impact of foreign direct investment was the study of Dritsakis and Stamatiou (2018), where the study examined the causal relationship between FDI and both exports, economic growth and unemployment for old 15 European countries during the time period from 1970 to 2015. Using panel data and based on the result of the Hausmann test, the Fixed Effect Model (FEM) was used. Using the panel VAR, the results showed a bidirectional causality relationship between FDI and exports, and a unidirectional causality relationship from FDI to both economic growth and unemployment.

However, many studies have shown the negative impact of human capital on economic growth and explained this for several reasons, the most important of which is lack of interest in educational outcomes, insufficient spending on education, interest in quantitative education rather than the quality of education, and in addition to not linking higher education outputs to the labor market. Also, with regard to the negative impact of foreign direct investment on economic growth, we find several studies that have shown that and explained the role that foreign investment may play in exploiting the host country's sources and increasing imports at the expense of exports, thus distorting the trade balance and increasing unemployment rates through operations Acquisition and merger, and that the majority of the profits of these foreign companies go abroad and that most of these investments focus on extractive industries so they do not have a clear impact on the transfer of technology from abroad to the host country. Among these studies: Hanushik Study (2013) which investigated the impact of education on economic growth in 50 countries, the study compared education in developed countries and education in developing countries. The study used panel data for the period from 1981 to 2008 and adopted a set of variables that represent human capital, which are cognitive skills, Share of students reaching basic literacy, Share of top-performing students, Years of non-tertiary schooling, Years of tertiary schooling and Initial years of schooling. The results of the research paper showed the positive effect of human capital in developed countries, while showing the negative impact in developing countries. The findings also showed that the gap in quality education between the two country groups has increased despite the improvement in quantitative education indicators and figures in developing countries. In Jozicic's paper (2016), the paper examined the impact of human capital on economic growth in Croatia, in addition to conducting an evaluation of the educational 
system by examining the quality of education and the proportion of investment in education and a comparison between education spending in Croatia and its counterpart in OECD countries. The study used quantitative education indicators as indicators that represent the quality of education as the numbers of completed years of study, and the results show and explain the negative impact of the human capital represented by the educational system on the economic growth in Croatia. The study attributed the reason to the decrease in spending on education as a percentage of GDP compared to the countries of the OECD or the countries of the European Union. The study also warned that the lack of investment in education is one of the reasons that limit the economic development process. With regard to Sharma (2019), the study carried out research into the impact of education and health on economic growth in both China and India during the period from 1970 to 2019, the health index and education index were used as representative variables of health and education where these indicators were built using the Principal Component Analysis (PCA) method. The study also examined the effect of spending on health and education on the economic growth of both countries, and by using Vector auto regression (VAR) model, the causality test (Granger causality) was done, and the results showed the bidirectional causality between the expenditure on health and economic growth in both India and China. Findings also illustrated the positive effect of the health and education index in India, while negative effect of both indicators In China.

On the other hand, Aitken and Harrison (1999) study, which aims to estimate the impact of foreign direct investment on small and large Venezuelan factories, where the study considered that factories and small enterprises have less than 50 employees, and large ones that exceed 50 employees. Using panel data and Common Effect Model (CEM) for more than 4,000 factories and institutions during the time period from 1976 to 1989, the results showed a negative impact of foreign direct investment on local small factories and a positive impact on jointly owned small factories, and the results also showed a negative impact on large factories. As Pandya and Sisombat (2017) study examined the impact of foreign direct investment on economic growth, employment, and exports in the Australian economy. The study relied on a series of time data from 2001 to 2013, and the study focused on the mining and quarrying sector as it is one of the important sectors in the gross domestic product and contributes $7 \%$ of it, and it is also one of the sectors attracting foreign investment. The study used the multiple regression model, and the results showed the absence of the impact of foreign investment on the measures of the Australian economy. According to the Saqib, Masnoon and Rafique study (2013), which compared the impact of domestic investment and foreign direct investment on the growth of the gross domestic product of the Pakistani economy during the time period from 1981 to 2010 . Using the unit root tests and the common integration test, the results showed that there is a co-integration relationship in the long run between the study variables. The study relied on the linear model to investigate the impact of both domestic investment, external debt, foreign trade and inflation in addition to FDI on economic growth and through the method of regular small squares (OLS) the impact of domestic investment was positive while FDI was negative. Finally, Dinh, Hong Vo, The Vo and Nguyen (2019) paper aimed to study the effect of foreign direct investment on 30 low-middle-income economies during the time period of 2000 to 2014. The study used the traditional linear economic model. The independent variables were FDI, domestic credit for the private sector, 
gross domestic investment, money supply, and human capital. And the dependent variable is growth in GDP. The study was interested in finding the relationship between the variables in the long and short term and the common co-integration relationship, so it used the panel unit root for and the Co-integration test (Johansen), the Vector Error Correction Model (VECM) and also to ensure the reliability of the analysis a Fully Modified OLS (FMOLS) was used. The results showed the positive impact of FDI in the long run, while showing the negative impact in the short term.

After reviewing the previous studies and defining the different methodologies used in these studies, we can say that this research paper that combines these two types of investments together (human capital and foreign direct investment) in Jordan is an added value to the literary library and an introduction to other studies that may use different methodologies and economic variables Other.

\section{Data and Methodology}

The study relied on a series of temporal data from 1984 to 2018, so that the study was interested in analyzing a sufficient time period to show the integrative relationship between the variables in the long term. The data series included: workers 'share of real gross domestic product (GWP), employee share of real capital growth (GWK), foreign direct investment (GFDI) growth and human capital index (HCI). The data was obtained through the World Development Indicators of the World Bank, the United Nations Development Program, the United Nations Conference on Trade and Development (UNCTAD), the Jordanian Statistics Department, the Jordanian Ministry of Labor and the Central Bank of Jordan. Figure 1 below shows the time evolution of the Human Capital Index (HCI), foreign direct investment (FDI) and average worker productivity (AWP) over the study period.
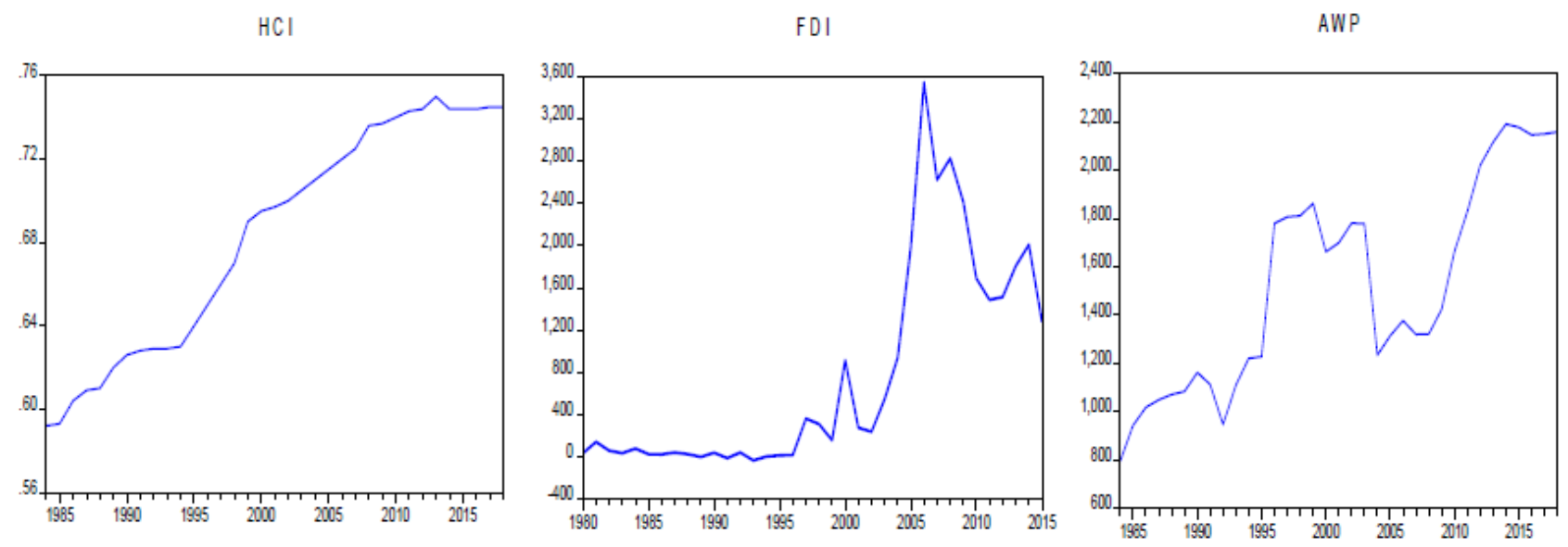

Figure 1. Time evolution of the study variables

What can be observed from Figure 1 is that AWP variable is irregular and fluctuates during the study period because the rate of increase in real Jordanian GDP for some of the study years is less than the rate of increase in the number of employees, in addition to the impact of 
structural adjustment programs (SAP), while HCI index is rising steadily. From the figure above we can note that FDI during the period 1990 and 2000 increased slowly but after 2000 Jordan followed the privatization approach and Jordan's opening of the free trade agreement led to a significant increase in FDI volume, then FDI decreased by the 2008 due to the consequence of the global financial crisis and Arab Spring (Arab Investment Climate Report, 2015).

It should be noted that, despite the continuous rise of the human capital index in Jordan during the study period, Jordan's ranking according to this indicator has decreased in recent years; Jordan ranked 67 in 1990 and rose to 77 in 2010 to continue to rise 85 in 2014 to reach 95 in 2018.

Experts attribute this to several reasons, the most important of which are the obstacles facing the education system in Jordan due to the low rate of enrollment in the vocational education track in all its specialties, where the rate of enrollment in vocational education dropped from $33 \%$ in 2000 to $26 \%$ in 2005 and 13\% 2012, to reach less than 11\% in 2018 (MOE, 2018).

In addition to the ratio of expenditure on education to GDP is low even when compared to middle-income countries. In Jordan, education has a spending rate of 3.4\% of GDP, Only 10\% of the State budget for 2018, which is below the United Nations recommendations to achieve the Millennium Development Goals, which states that the proportion of spending on education should reach $6 \%$ of GDP, and at least $20 \%$ of the State budget at least (UNESCO, 2018).

To achieve the objectives of this study, the average worker productivity (AWP) will be used as a variable representing economic growth by dividing the gross domestic product by the number of employees according to the usage survey issued by the Jordanian Statistics Department, which includes the number of workers with the exception of the armed forces, security services and informal sectors, in addition to Human Capital Index (HCI) as a variable representing investment in human capital (Agamiah, 2003). And to express human capital in physical units, the study used the Solo model which was developed and modified by the methodology of (Mankiw, Weil, Romer), as this model deals with human capital in the same way as physical capital and assumes it increases and decreases with the same technique of increasing and decreasing of physical capital (Gujarati and Porter, 2009).

The Solo model indicates that the volume of production $(\mathrm{Y})$ is determined by the factors of production (L) and capital (K) according to the equation (Todaro and Smith, 2015):

$$
\mathrm{Y}=\mathrm{F}(\mathrm{K}, \mathrm{L})
$$

By dividing the two sides on (L), the equation becomes as follows:

$$
\mathrm{Y} / \mathrm{L}=\mathrm{F}(\mathrm{K} / \mathrm{L})
$$

Whereas:

Y/L: The average productivity of the Jordanian worker (AWP).

K/L: Average Jordanian worker Share of Capital. 
In order to analyze the impact of human capital and FDI on economic growth in Jordan, the human capital Index (HCI) and FDI will be added to Equation (2), based on the hypothesis that human capital will accumulate in the same technique as the accumulation of physical capital. In accordance with Modified Solo model with MRW methodology, the equation is as follows:

$$
\mathrm{AWP}=\mathrm{Y} / \mathrm{L}=\mathrm{F}(\mathrm{K} / \mathrm{L}, \mathrm{HCI}, \mathrm{FDI})
$$

Since the study is based on the real values of the model variables attributed to the price index (CPI), the previous equation becomes as follows:

$$
\text { RAWP }=\mathrm{F}(\mathrm{RK} / \mathrm{L}, \mathrm{HCI}, \quad \mathrm{FDI})
$$

For the purposes of this study, and to know the effect of the change in the human capital and FDI inflows on the change in the economic growth, we will take the variables in terms of growth to become the equation in the following figure:

$$
\text { GRAWP }=F(\text { GRK/L, HCI, GRFDI })
$$

To estimate the model used in equation (5), the following mathematical formula will be used:

$$
G A W P=\beta_{0}+\beta_{1} G W S K_{t}+\beta_{2} G F D I_{t}+\beta_{3} H C I_{t}+U_{t}
$$

Where:

GAWP: growth of real average product of worker (economic growth).

GWSK: growth of average worker share of real capital.

GFDI: growth of real foreign direct investment inflows.

HCI: human capital index.

$\beta_{0}, \beta_{1}, \beta_{2}, \beta_{3}$ : Parameters of the model.

$\mathrm{U}$ : random error.

t: Time period.

During the study period, a group of economic and social tremors affected the Jordanian economy, the first of which was the Jordanian financial crisis in 1989 and 1990, which led to a sharp decline in the exchange rate of the Jordanian dinar against the US dollar, 2000 and 2001 as a result of the rapid shift towards privatization and the years 2008 and 2009 as a result of the global financial crisis, which negatively affected the Jordanian economy, like other economies in the world, and finally in 2013 due to the Syrian displacement crisis and Jordan's reception of more than a million and a half refugees. During these years, Jordanian governments followed the Structural Adjustment Program (SAP) imposed by the International Monetary Fund (Engle, 1969). Therefore, the study used Dummy variable as a variable representing this program during these years so equation No. (6) becomes as follows:

$$
G A W P=\beta_{0}+\beta_{1} G W S K_{t}+\beta_{2} G F D I_{t}+\beta_{3} H C I_{t}+D u m+U_{t}
$$




\section{Empirical Result and Discussion}

Diagnostic tests were carried out to use the appropriate standard model to analyze data during the study period (1984-2018). These diagnostic tests include the stationary unit root tests (the augmented Dicky Fuller test), the Autocorrelation test, the Hetroscedasticity test, normal distribution test and bounds test. As the Auto Regressive Distributed Lag Bounds Testing approach (ARDLBT) was used as a statistical analysis tool (Pesaran et. al, 2002).

Table 1. Results of ADF unit root test

\begin{tabular}{|l|l|l|l|}
\hline Variables & Panel A: Level & Panel B: 1 st difference & Results \\
\hline & Actual value & Actual value & \\
\hline GAWP & $-5.4996 * * *$ & -7.8974 & $\mathrm{I}(0)$ \\
\hline GWSK & $-5.5288^{* * *}$ & -5.8903 & $\mathrm{I}(0)$ \\
\hline GFDI & -1.9341 & $-6.0173 * * *$ & $\mathrm{I}(1)$ \\
\hline HCI & -1.8688 & $-3.9732 * * *$ & $\mathrm{I}(1)$ \\
\hline
\end{tabular}

Notes: Maximum lag order is set to two and optimal lag order (k) is selected based on Schwarz criterion in ADF test; *,** and *** accordingly indicate rejection of null hypothesis at $10 \%, 5 \%$ and $1 \%$ significance levels; critical values are taken from the table prepared by MacKinnonun (1996). Time period: 1984- 2018.

As next step, the time series of (GWP) and (GWSK) are static at level, and the time series (GFDI) and (HCI) become static after the first difference, and for the possibility of a long-term equilibrium relationship, ARDLBT was used by using the bound test proposed by Pesaran (Pesaran and Shin, 1999).

Table 2. The co-integration test results for $\operatorname{ARDL}(2,2,2,0)$

\begin{tabular}{|l|l|l|l|}
\hline F- statistic & Significance level & Low bound & Upper bound \\
\hline$F W=7.27$ & $10 \%$ & 2.2 & 3.09 \\
\cline { 2 - 4 } & $5 \%$ & 2.56 & 3.49 \\
\cline { 2 - 4 } & $2.5 \%$ & 2.88 & 3.87 \\
\cline { 2 - 4 } & $1 \%$ & 3.29 & 4.37 \\
\hline
\end{tabular}

Notes: The value of F- statistic $=7.27$ is greater than Bound I1 and thus negates the null hypotheses (no long- run relationship exist) and there is a long term common integration among the variables.

Since the variables showed a common integration, this indicates a long-term equilibrium relationship between these variables, therefore ARDL model was then used to estimate the long-term relationship and the results were as follows: 
Table 3. Results in the long term.

Panel A: ARDL Co integrating And Long Run Form

Dependent Variable: GWP

Selected Model: ARDL $(2,2,2,2,0)$

Sample: 19842018

Included observations: 33

\begin{tabular}{|l|l|l|l|}
\hline Variables & Coefficient & St. error & t- statistic \\
\hline GWSK & $1.254952 * * *$ & 0.123374 & 10.171965 \\
\hline FDI & $0.006013 * * *$ & 0.001554 & 3.869686 \\
\hline HCI & $-0.272135 *$ & 0.154909 & -1.756738 \\
\hline DUM & -0.007594 & 0.012693 & -0.598267 \\
\hline Intercept & 0.135510 & 0.104018 & 1.302755 \\
\hline Panel B: ARDL & & \\
\hline
\end{tabular}

Panel B: ARDL specification.

ARDL $(2,2,2,2,0):$ Cointq $=$ GWP $-(1.2540 *$ GWSK+ $0.006 *$ GFDI $-0.2721 * \mathrm{HCI}-$ $0.0076 * \mathrm{DUM}+0.1355)$.

Panel C: Residual Diagnostics and Misspecification test results for ARDL $(2,2,2,2,0)$.

$\chi_{S C}^{2}(\mathbf{2})=0.761 \quad[0.683], \quad \chi_{A R C H}^{2}(\mathbf{1})=1.367[0.2422], \quad J B_{N}=1.297 \quad[0.523], \quad \boldsymbol{F}_{\text {statistic }}=11.066$ [0.0000] R-squared $=0.8691$, Adjusted $R$-squared $=0.7905$.

Notes: $*, * *$, and $* * *$ indicate significant level at $\mathbf{1 0} \%, \mathbf{5} \%$ and $1 \%, \quad \chi_{A R C H}^{2}$ denote Chi-squared statistics to test the null hypotheses of no serial correlation, no autoregressive conditioned heteroscedasticity, and; $\boldsymbol{J} \boldsymbol{B}_{\boldsymbol{N}}$ and $\boldsymbol{F}_{\boldsymbol{F} \boldsymbol{F}}$ indicate Jarque-Bera and F-statistic to test the null hypotheses of normal distribution and the significance probability of the model respectively, and; R-squared and Adjusted R-squared to indicates the ability of independent variables to interpret the dependent variable change.

Table 3 shows that the estimated parameters of the independent and long- term variables, and through the above model we observe the following:

The results show that the adjusted-R square (adj- R2) was 79.0\%. This means the independent variables combined explain $79.0 \%$ of the change in the economic growth, and the results indicate that all parameters in the model are statistically acceptable (GWSK at $1 \%$ significant level, GFDI at $1 \%$ significant level and HCI at $10 \%$ significant level).

For Growth in the worker share of capital (GWSK) coefficient, we note that it is positive, and this result is consistent with the logic of economic theory, if (GWSK) increases by $1 \%$, economic growth (GWP) will increase by $1.254 \%$, with the stability of other factors.

For the growth of FDI (GFDI) coefficient, we note that it is positive, if the (GFDI) increases $1 \%$, the economic growth (GWP) will increase by $0.006 \%$, with the stability of other factors. This result is consistent with the logic of the economic theory and the reality of the Jordanian economy during the period of study which indicates that economic growth are developing and growing in the same direction as foreign direct investment because foreign companies 
invest not only to supply the local market but also to supply foreign market, especially Arab Gulf market. The results of this study are consistent with many previous studies such as the study of Selim, Reci and Sadiku (2016) showed that there is a positive effect of foreign investment on exports in the eastern Balkan countries and the study of Mukhtarov and Alalawneh (2019) showed the positive effect of direct foreign investment on exports Jordan.

According to the Human Capital Index (HCI) factor, we note that it is negative, if (HCI) increases $1 \%$, economic growth (GWP) will decrease by $0.272 \%$, as other factors stabilize. The researcher believes that this is an indication of the size of obstacles and problems facing human investment and human development as a whole in Jordan, the most important of which are the problems of the education system in terms of low demand for vocational education and low spending on education as a percentage of GDP. This result is consistent with Jordan's rating in the human capital index; despite the steady rise in the value of the index, Jordan's rating decreased from 67 in 1990 to 95 in 2018. This result also confirms the steady rise in the unemployment rate in Jordan in recent years, which is one of the main reasons for the inconsistency between university study and the requirements of the labor market, where unemployment reached $18.6 \%$ in 2018, and this percentage is considered high and a dangerous indicator.

The results of this study are consistent with some foreign and domestic studies, such as the Jozicic study (2016), which showed the negative impact of human capital on economic growth in Croatia, where the study attributed the reason to weak government spending on education as a proportion of public spending or as a proportion of GDP . The Sharma Study (2019) also showed the negative impact of human capital represented by education and health on economic growth in China.

In terms of local studies, this study was also compatible with the study of Al-Tal (1991), which showed the negative impact of education on economic growth in Jordan, where the study attributed the reason to weak government spending on education and a significant decrease in the demand for vocational education compared to academic education.

\section{Conclusion}

After completing the empirical analysis and discussing the results, we can summarize them as follows: There is a long- term common integrative relationship between the explanatory variables (GWSK, GFDI, HCI) and the explained variable (GWP), there is a positive and statistically significant relationship between Growth in the worker share of capital (GWSK) to economic growth (GWP) and between Growth in FDI (GFDI) to economic growth (GWP). Finally there is a negative and statistically significant relationship between Human Capital Index (HCI) to economic growth (GWP). We note that the result of the study with regard to human capital is consistent with some of the results of other studies. The Hanushik study (2013) demonstrated the negative impact of human capital on the economic growth of developing countries, and we also find in the Jozicic study (2016) the negative impact of human capital on economic growth in Croatia, and with regard to local studies we also see the result matchs with the study of Altal (1991), which showed the negative impact of education on Jordanian economic growth. Regarding FDI, we also find a study of Dritsakis 
and Stamatiou (2018) which showed a bidirectional causal relationship between FDI and exports and unidirectional causal with both economic growth and unemployment in 15 old countries in the European Union, and also the study result is compatible with the Mukhtarov and Al-Alawneh (2019) study, which showed the positive impact of FDI on exports in Jordan.

Depending on the results of the study, some recommendations can be identified, including:

The researcher emphasizes that there is no magic solution to achieve economic growth through the development of human capital, and that this process is a long-term process that requires the government to care and pay attention to individuals in terms of educational level, health and vocational and technical training. In addition to developing the educational process in all its stages, and focusing on vocational education, and linking educational and health institutions with different research and development centers to see the experiences of different countries, especially those that have achieved economic growth and comprehensive development through investment in human capital such as Singapore and Finland. And the study recommends increasing the spending on the education as a share of GDP and public spending.

The study also recommends that the government enact a set of legislations and laws containing a number of facilities to provide an investment environment without barriers or obstacles. These include tax and customs exemptions, income and profit exemptions, social services, land taxes, incentives for the transfer of capital, salaries, wages of foreign workers and capital returns.

\section{Conflict of Interest}

The author declares that there is no conflict of interests regarding the publication of this manuscript. In addition, the ethical issues, including plagiarism, informed consent, misconduct, data fabrication and/or falsification, double publication and/or submission, and redundancies have been completely observed by the author.

\section{References}

Aitken, B. J., \& Harrison, A. E. (1999). Do Domestic Firms Benefit From Direct Foreign Investment? Evidence From Venezuela, American Economic Review, 89(3), 605-618. http://dx.doi.org/10.1257/aer.89.3.605

Ajamieh, M. (2003). Economic development: theoretical and applied studies, First Edition, Alexandria University, Egypt.

Alalawneh, M., \& Ibrahimov, M. (2018). The Impact of Human Capital Development on the Average Labor Productivity. Journal Tax, 137(2), 121-137. [Online] Available: https://www.academia.edu/40969734/

Arab Investment Guarantee and Export Credit Corporation (2015). Arab Investment Climate Report 2015, sporadic preparation. [Online] Available:

http://dhaman.net/en/research-studies/investment-climate-report-latest/

Carkovic M., \& Levine, R. E. (2002). Does foreign direct investment accelerate economic 
growth? University of Minnesota Department of finances Working. https://doi.org/10.2139/ssrn.314924

Chuang, Y. (2000). Human Capital, Export and Economics: A causality Analysis for Taiwan (1952 - 1995). Review of International Economics, 4(8), 712-720.

https://doi.org/10.1111/1467-9396.00252

Central Bank of Jordan. Annual Statistical Data: Price Sector (1984-2018). [Online] Available: http://www.cbj.gov.jo/Pages/viewpage.aspx?pageID=337.

Central Bank of Jordan. Annual Statistical Data: Production Sector (1984-2018). [Online] Available: http://www.cbj.gov.jo/Pages/viewpage.aspx?pageID=235.

Department of Statistics. Survey of Use, Hashemite Kingdom of Jordan, (1984-2018). [Online] Available: http://dosweb.dos.gov.jo/ar/product-category/emp-unemp-ar/.

Diebolt, C., \& Hippe, R. (2019). The long-run impact of human capital on innovation and economic development in the regions of Europe. Applied Economics, 51(5), 542-563. https://doi.org/10.1080/00036846.2018.1495820

Dinh, T., Hong, Duc., The Vo, A., \& Nguyen, T. (2019). Foreign Direct Investment and Economic Growth in the Short Run and Long Run: Empirical Evidence from Developing Countries. Journal of Risk and Financial Management, 12(4), 1-11.

https://doi.org/10.3390/jrfm12040176

Dkhili, H., \& Dhiab, L. B. (2018). The Relationship between Economic Freedom and FDI versus Economic Growth: Evidence from the GCC Countries. Journal of Risk and Financial Management, 81(11), 1-17. https://doi.org/10.3390/jrfm11040081

Dutt, A. (2006). Globalization, Trade Liberalization and Conflict: A Southern Perspective. In B. N. Ghosh \& H. M. Guven (Eds.), Globalization and the Third World (pp. 223-250). Palgrave Macmillan, London. https://doi.org/10.1057/9780230502567_14

Engle, R. (1969). Investing Causal Relation by Econometric Models and Cross - Spectral Methods. Econometrica, 37(3), 424. https://doi.org/10.2307/1912791

Goncz, E., Skerki, U., Kleizen, H., \& Barber, M. (2007). Increasing the rate of sustainable change: a call for redefinition of the concept and the model of its implementation. Journal of Cleaner Production, 6(15), 525-537. https://doi.org/10.1016/j.jclepro.2006.05.018

Griffin, K., \& McKinley, T. (1992). Towards A human Development Strategy. UNDP- HDRO Occasional Paper 6, 1992/2. https://doi.org/10.2139/ssrn.2273858

Gujarati, D., \& Porter, D. (2009). Basic Econometrics, The Fifth Edition, McGraw Hill, Boston. [Online] Available: https://www.academia.edu/15273562.

Hanushek, E. (2013). Economic Growth in Developing Countries: The Role of Human Capital. Economics of Education Review, 37, 204-212.

https://doi.org/10.1016/j.econedurev.2013.04.005 
Jozicic, K., \& Skare, M. (2016). A review of theoretical and empirical research on human capital quality in Croatia. Review of Innovation and Competitiveness, 2(2), 67-96.

https://doi.org/10.32728/ric.2016.22/2

Kanchan, C. (2001). Social Capital and Development Process: The Role of Formal and Informal Institutions. Economic and Political Weekly, 37(28), 2911-2916.

Kartal, Z., Zhumasheva, A., \& Acaroglu, H. (2017). The Effect of Human Capital on Economic Growth: A Time Series Analysis for Turkey, Regional Studies on Economic Growth, Financial Economics and Management. Eurasian Studies in Business and Economics, 7, 175-191. https://doi.org/10.1007/978-3-319-54112-9_11

Ministry of Education (2018). Annual Report, Jordan. [Online] Available: http://www.moe.gov.jo/ar/reports

Ministry of Labor. Annual Report: various issues, Hashemite Kingdom of Jordan. [Online] Available: http://www.mol.gov.jo/Pages/viewpage.aspx?pageID=292.

Mukhtarov, S., Alalawneh, M., Ibadov, E., \& Huseynli, A. (2019). The impact of foreign direct investment on the export in Jordan: An empirical analysis. Journal of International studies, 12(3), 38-47. https://doi.org/10.14254/2071-8330.2019/12-3/4

Pandya, V., \& Sisombat, S. (2017). Impacts of Foreign Direct Investment on Economic Growth: Empirical Evidence from Australian Economy. International Journal of Economics and Finance, 9(5), 121-131. https://doi.org/10.5539/ijef.v9n5p121

Pelinescu, E. (2015). The Impact of Human Capital on Economic Growth. Procedia Economics and Finance, 22, 184-190. https://doi.org/10.1016/S2212-5671(15)00258-0

Pesaran, M., Shin, Y., \& Smith, R. (2001). Bounds testing approaches to the analysis of level relationships. Journal of Applied Econometrics, 16(8), 289-326.

https://doi.org/10.1002/jae.616

Pesaran, M., \& Shin, Y. (1999). An autoregressive distributed lag modeling approach to cointegration analysis. Cambridge University Press, pp. 371-413.

https://doi.org/10.1017/CCOL521633230.011

Saqeb, N., Masnoon, M., \& Rafique, N. (2013). Impact of Foreign Direct Investment on Economic Growth of Pakistan. Advances in Management \& Applied Economics, 3(1), 35-45. [Online] Available: https://www.researchgate.net/publication/254956854

Selim, N., Sadiku, L., \& Kushtrim, R. (2016). The impact of FDI on the export performance: Empirical evidence for Western Balkan countries. ILIRIA International Review, 6(1), 57-66. https://doi.org/10.21113/iir.v6i1.235

Sharma, P. (2019). Role of Human Capital in Economic Growth: A Comparative Study of India and China, SSRN, 1-33. https://doi.org/10.2139/ssrn.3319224

Todaro, M., \& Smith, S. (2015). Economic Development, Eleventh Edition, PEARSON, Boston. [Online] Available: 
https://www.pearson.com/uk/educators/higher-education-educators.html

UNCTAD (2010). World Investment Report, FDI From Developing and Transition Economics: Implications For Development (2010), U.N, New York. [Online] Available:

http://www.unctad.org/en/docs/wir2010_en.pdf

UNCTAD (2015). World Investment Report, FDI From Developing and Transition Economics: Implications For Development (2015), U.N, New York. [Online] Available:

http://www.unctad.org/en/docs/wir2015_en.pdf

United Nations (2005). Transnational Corporations and the Internationalization of R\&D: World Investment Report (2005), UNCTAD. [Online] Available:

https://unctad.org/en/pages/PublicationArchive.aspx?publicationid=693.

United Nations Development Program. Human Development Report: Data in Jordan (1984-2018). [Online] Available: http://hdr.undp.org/en/data

United Nation of Education. Science and Culture Organization: UNESCO Index of Human Development of Jordan, (1984-2018). [Online] Available: http://uis.unesco.org/en/country/jo

World Bank. National Accounts Data: Jordan (1984-2018). [Online] Available:

https://data.worldbank.org/country/jordan

\section{Copyright Disclaimer}

Copyright for this article is retained by the author(s), with first publication rights granted to the journal.

This is an open-access article distributed under the terms and conditions of the Creative Commons Attribution license (http://creativecommons.org/licenses/by/4.0/). 